Article

\title{
Sustainability Leadership in Higher Education Institutions: An Overview of Challenges
}

\author{
Walter Leal Filho ${ }^{1}{ }^{\mathbb{D}}$, João Henrique Paulino Pires Eustachio ${ }^{2} \mathbb{D}^{\mathbb{B}}$, \\ Adriana Cristina Ferreira Caldana ${ }^{2}\left(\mathbb{D}\right.$, Markus Will ${ }^{3, *(\mathbb{D}}$, Amanda Lange Salvia ${ }^{1}(\mathbb{D}$, \\ Izabela S. Rampasso ${ }^{4}{ }^{(0)}$, Rosley Anholon ${ }^{4}$, Johannes Platje ${ }^{5}$ and Marina Kovaleva ${ }^{1}$ \\ 1 European School of Sustainability Science and Research, Hamburg University of Applied Sciences, \\ 20099 Hamburg, Germany; walter.leal2@haw-hamburg.de (W.L.F.); amandasalvia@gmail.com (A.L.S.); \\ Marina.Kovaleva@haw-hamburg.de (M.K.) \\ 2 School of Economics, Business Administration and Accounting at Ribeirão Preto, University of São Paulo, \\ Ribeirão Preto 14040-905, Brazil; eustachio@usp.br (J.H.P.P.E.); caldana@usp.br (A.C.F.C.) \\ 3 Faculty Natural Sciences and Environmental Sciences, Zittau/Görlitz University of Applied Sciences, \\ 02763 Zittau, Germany \\ 4 Department of Manufacturing Engineering and Materials, State University of Campinas, \\ Campinas 13083-970, Brazil; izarampasso@gmail.com (I.S.R.); rosley@fem.unicamp.br (R.A.) \\ 5 Faculty of Finance and Management, WSB University in Wroclaw, 53-609 Wroclaw, Poland; \\ johannes.platje@wsb.wroclaw.pl \\ * Correspondence: m.will@hszg.de
}

Received: 12 April 2020; Accepted: 28 April 2020; Published: 6 May 2020

check for updates

\begin{abstract}
Sustainability leadership entails the processes, which leaders, policymakers, and academics undertake in order to implement sustainable development policies and other initiatives within their organizations. It encompasses approaches, methods, and systemic solutions to solve problems and drive institutional policy towards a more sustainable organization. Higher Education Institutions (HEI) play a particularly important role, especially with regard to their institutional leadership role in promoting sustainable development. There is a paucity of research focusing on sustainability leadership in universities. In order to address this gap, this paper discussed the concept of sustainability leadership based on literature and empirical insights. The study aimed to understand the main characteristics of sustainability leaders at HEI and the main challenges they are confronted with. Secondary research questions involved gender issues and positive outcomes of sustainability leadership. The empirical component of the study consisted of an online-questionnaire survey performed among leaders $(n=50)$ from a set of universities in 29 countries. The sampling scheme was purposive, based on the membership in the Inter-University Sustainable Development Research Program (IUSDRP). The study was explorative in nature, and the descriptive statistics were used for the analysis. Due to the purposive sampling, the participants from top management positions could be considered as experienced, and their views were assumed to be information-rich. With a self-evaluation, the respondents described their leadership style and their usual traits, with inclusive style and systemic thinking being predominant in the sample. Regarding the skills, the respondents selected the ability to innovate, to think long-term, and to manage complexity from a pre-defined set of options. Connectedness with interdisciplinarity and knowledge about organizational settings, as well as global challenges and dilemmas, were stated as important issues related to the knowledge required for being a leader. Regarding requirements for a change towards more sustainable universities' curriculum adaptation, investments in education for sustainable development (ESD), sustainable procurement, and reporting were mentioned. The study also revealed that gender issues were taken seriously among the sampled institutions, which is an encouraging trend. Challenges seen in implementing sustainability leadership are, for instance, a lack of interest by the university administration and among some members of the academic community, as well as lack of expertise and materials or resources. Based on the empirical insights, a set of measures were listed and
\end{abstract}


which may be adopted in the future, so as to allow leaders of Higher Education Institutions to enhance their sustainability performance.

Keywords: leadership; sustainability in higher education institutions

\section{Introduction}

Organizations generate positive and negative externalities along with their processes of creating and delivering value to their several stakeholders [1]. The negative ones can affect the economic, social, and environmental systems, interfering with the process of achieving sustainable development (SD).

In this context, due to several charters and initiatives, such as the Principles for Responsible Management Education (PRME), the Higher Education Institutions (HEIs) perceive to assume an important role for sustainable development. These universities have been adapting themselves and redirecting their actions by developing their institutional leadership role in promoting SD; caring about their educational system and top management teams, staff, professors, and researchers as sustainable leaders, and encouraging the development and education of tomorrow's leaders who will assume important positions at companies, NGOs, and government.

Regarding the perspective of the HEIs as sustainable leaders, they must become change actors, considering the needs of present and future generations and encouraging professionals that are adept and aware of SD [2]. This implies that the whole university system should become oriented to educate students that will be capable of leading different types of organizations, in a responsible way, towards sustainable societal patterns [2].

Still, in a complementary way to the definition by Lozano and colleagues (2013), sustainable leadership is also explored from a theoretical perspective of how sustainable development can be connected to different leadership approaches, such as traits/style school, context/situational school, and interactionism/contingency school. Thus, the term sustainability leadership or, more specifically, leadership for sustainability could be expressed as a combination of different leadership approaches in a defined context (in this case, sustainable development) [3].

Academic inquiry of leadership is mainly related to the practical skills of an organization or individual to guide followers (i.e., employees and team members) and to take actions that have a considerable effect on the outcomes of an organization [4-6]. Leadership, as an activity and a role, is especially vital whenever the state of a system or organization needs to be transformed, which always creates uncertainty $[7,8]$.

There is some overlap with the term management, i.e., individuals in a management position are assumed to be leaders, but not all managers lead [9-11]. Management and leadership can be considered as distinct but complementary systems of actions within an organization. Leadership is often concerned with change management [12-14] and with preserving a 'structural tension' from which pursuing a shared vision is fuelled [15]. Leadership involves aligning people with this vision, as well as motivating and empowering them. Management, in contrast, is coping with complexity [12] and advocates stability and preserving established routines [16]. Management involves, for instance, planning and budgeting, organizing and staffing, controlling, and troubleshooting related to day-to-day problems [17]. Table 1 provides a summary of how management differs from leadership.

Traditional leadership theory is concerned with the role of a leader, which is considered most often to be a 'great man'. In this heroic and 'male' understanding of the leadership role, the gender perspective has been discussed later, the 'great men' bear all the burdens and work hard to achieve a particular goal where losing is punished. Those 'great men' are also considered to be 'born to lead', while other people will follow them. The heroic approach to leadership has deep roots in the military and rather aggressive solutions to problem-solving and is still to be found in most (organizational) cultures [18]. Another strand of leadership research is led by the 'upper echelons hypothesis' $[4,19]$, 
according to which a small group of executives, known as the top management team (TMT), occupies the positions at the top of the organization and have a significant effect on organizational outcomes.

Table 1. Differences between leadership and management $[11,14,18]$.

\begin{tabular}{|c|c|c|}
\hline & Leadership & Management \\
\hline $\begin{array}{l}\text { Agenda and } \\
\text { goal setting }\end{array}$ & $\begin{array}{l}\text { Develops and articulate a vision, establishes } \\
\text { directions, develop change strategies }\end{array}$ & $\begin{array}{l}\text { Executes plans, improves the present, } \\
\text { creates detailed steps/time tables }\end{array}$ \\
\hline Way of thinking & $\begin{array}{l}\text { Focuses on people, looks outward, } \\
\text { "sees the forest" }\end{array}$ & $\begin{array}{c}\text { Concentrates on issues, looks inward, } \\
\text { "sees the trees" }\end{array}$ \\
\hline Employee relations & Empowers colleagues, trusts, and develops & $\begin{array}{l}\text { Controls subordinates, directs, } \\
\text { and coordinates }\end{array}$ \\
\hline $\begin{array}{l}\text { Mode of execution } \\
\text { and operation }\end{array}$ & $\begin{array}{l}\text { Does the right things, inspires, creates } \\
\text { change, serves subordinates }\end{array}$ & $\begin{array}{l}\text { Does the things right, manages change, } \\
\text { controls, and organizes to solve problems, } \\
\text { serves superordinates }\end{array}$ \\
\hline Governance & $\begin{array}{l}\text { Uses influence, uses conflict, and acts } \\
\text { decisively, inspires and energizes others to } \\
\text { overcome barriers }\end{array}$ & $\begin{array}{l}\text { Uses authority, avoids conflicts, and acts } \\
\text { responsibly, organizes to solve problems }\end{array}$ \\
\hline Outcomes & Potentially revolutionary change & Consistent key results \\
\hline
\end{tabular}

More recently, a view has spread that it is not a question of position in an organization that constitutes leadership, but that there is a phenomenon, i.e., leading when one is not in charge [19] or leading from behind [20].

When related to leadership and sustainable development, where the aim is to find a balance between financial/economical and socio-ecological interests, a particular new view of leadership is established [21]. This new view on leadership challenges the traditional assumptions made; for instance, that a respected leader (or top management team) fulfills a designated role, stands somewhat above the people, and knows and determines the best course of action [21]. Sustainability leadership is understood to be concerned with creating current and future benefits while improving the lives of all actors concerned $[22,23]$ and points to a different view of leadership that assumes [21] that:

- sustainability problems are complicated or even wicked problems, i.e., related to phenomena that cannot be reduced to manageable parts separate from the seamless web they are part of. Hence, Newtonian and mechanistic approaches to problems solving are expected to fail

- $\quad$ anyone can choose to take responsibility to foster more sustainable conditions in workplaces or communities; therefore, anyone can become a leader

- the role of a leader involves co-generation and learning, instead of being a leader over and of other people

In this way, universities need leadership to create strategies with the vision of the future and connecting key-areas, involving stakeholders through coaching processes, inspiring people, and making communities stronger by adaptation [24] in order to manage and support all these challenges and demands. Thus, leaders need to understand and be aware of the several externalities of their activities on the systems and environments in which they interact (Foundation for deep ecology, 2012 apud [25]).

Besides the evolution of sustainability leadership concepts listed above, the trend in the literature, discussing the importance of leaders in top management teams and the role of HEIs (Higher Education Institutions) in contributing to sustainable development, needs further exploration.

Although this seems to be an evident and important issue, the literature has not fully explored the current scenario of leaders and top-management representatives from a set of universities from around the world yet. Against this background, the aim of the study was to collect information about attitudes and opinions on sustainability leadership from an international group of professionals by conducting a survey to collect information from an international sample. From this, recommendations were derived as to how the difficulties identified could be addressed. 
Therefore, to work with this objective, the five subsequent items were developed: The literature review discusses relevant literature on sustainability leadership at universities. The next section describes the methods and techniques used to address the objective of this article. After that, the output of this research was developed into three different topics: sample analysis and commitment to sustainability, self-evaluation and requirements concerning sustainability leadership, and gender inequalities. Finally, the conclusion section highlights the main findings and addresses theoretical and practical implications, discussing some ideas for future research.

\section{Sustainability Leadership at Universities}

It is common sense in the literature that human beings are moving social and environmental systems far beyond the limits of viability [26,27]. Hence, there is a commonly known need to pursue sustainable development that, according to the Brundtland's Commission, means understanding the needs in order to meet the expectations of the current generation while respecting the demands of the coming generations. Sustainable development should be based on the principles of balance and stewardship [1].

In the journey of pursuing sustainable management, there are several tensions [28] in which trying to achieve sustainability in a given company could compromise other objectives (i.e., the higher level of sales, profit, and meeting the concern of investors). One of these tensions relies upon the fact that organizations produce negative externalities [1] and have to mitigate them in order to create and capture sustainable value to its several stakeholders [29].

Once positive externalities are desirable and negative ones should be mitigated, the discussion of sustainability leadership becomes essential at the organizational level $[1,30]$. In line with this, a couple of initiatives were created by the UN to foster SD actions in organizations. The United Nations Global compact exists to connect strategies and operations of companies into the sustainable development goals (SDG), working with the recently developed instrument-the SDG Compass. Also, the PRME (Principles for Responsible Management Education) aim to prepare future leaders of sustainable organizations with the capacity to be change-agents in society [31].

All these initiatives have an effect, not only on the organization's sustainability and HEIs but also on society and local communities [32-34]. The initiatives present an excellent opportunity to engage diverse actors of HEIs and focus on the challenges today's society face, as well as achieving essential results towards sustainability $[33,35]$.

Besides UN initiatives and the authors' discussions on the importance of organizational leadership, there is another strand that discusses sustainability leadership at the individual level. Visser and Courtice (2011) brought this issue through a sustainability leadership model based on the situational leadership theory [36-38], considering three dimensions: leadership context (the internal and external environments of organizations), the individual as a leader (with its traits, styles, skills, and knowledge), and leadership's internal and external actions.

It is known that sustainability leaders can promote positive externalities in the market and inside companies. Today's students that absorb the sustainability culture could become sustainable leaders of tomorrow. They may guide organizations to pass through an adaptive process of learning [39] towards a more sustainable state, capable of dealing with complexity and goal conflicts between the social, economic, and environmental aspects [21]. In other words, these leaders need to have systems thinking competencies [40] and be able to think outside of the box [3,41] to overcome wicked sustainability challenges.

In this sense, developing leadership and empowerment of students should be seen as not only an effort by universities but from a systemic and situational perspective. In this sense, three other dimensions of sustainability leadership development are discussed: the leader perspective, the actions, and the context in which the leader-follower dyad is being established $[3,37,38]$.

Besides the importance of the perspective of the management team and the role of academics as leaders in the Institutions of Higher Education (IHEs) [42-45], the development of students as sustainability leaders also should be taken into account. There is a tendency in the literature to consider 
not only how sustainability leadership occurs in university management teams but also the perspective of the students. In other words, through the bottom-up empowerment of students as being change agents [46,47].

From the perspective of the individual, the style adopted by the leader, such as inclusive [3], visionary [48], creative [49], and altruistic [50], could contribute to sustainability leadership practices. There is also a vast literature, studying if they (leader or follower) have a set of competencies, values, knowledge, and skills, which makes them engage in leadership that seeks to preserve the earth's systems [40,51-61].

To increase the performance of a leader, it is important to develop leadership. That means fostering specific skills and capabilities, which will be needed by the leader during its job fulfillment [62]. Some methods for leadership development exist in the literature, such as multilateral feedback, executive coaching, mentorship, and networking. Still, these methods are not yet fully empirically tested, so one cannot fully confirm its effectiveness [62].

The discussion of gender, women in leadership positions, has gained increasing interest in research [63-71]. That is since women in many countries represent almost half of the workforce, but are underrepresented in leadership positions [72]. The industry sector and the role performed inside the company are influencing factors for women in top-positions [62], and much has been discussed about the effectiveness of leadership composition [72].

Besides the individual characteristics of a leader and the relationship established by the dyad leader-follower, there is another significant aspect of whether or not sustainability leadership would be a success-the context [73-75]. At this point, Visser and Courtice (2011) added to this framework [3] that sustainability leadership also needs to consider the external context (ecological, economic, political, cultural, and community) and the internal context (sector, industry, organizational reach, organizational culture, governance structure, and leadership role).

It is worth considering that universities also could be seen as institutional leaders in the effort of promoting sustainability. Universities may contribute to the sustainable development of their region and are recognized as pivotal institutions that can deal with problems, as well as provide the education of future leaders and the development of sustainable solutions for the future [2,76-80]. The PRME and SDG inclusion in universities' activities reflect the need to focus not only on teaching and researching but also in developing new paradigms related to sustainability [78]. It transforms society, whether from its students, the surrounding community, staff, or professors.

The university's engagement with sustainability is a challenge [81,82], and it can be motivated by the institution's interest in enabling a new organization form and action focus [83] by its high administration team [84]. The universities also seek to implement sustainability in many other ways. They formulate principles or are signing declarations (e.g., global compact and PRME) or integrate sustainability into their curricula. Sometimes, wholly new educational institutions are created, adapting both the mission and management of the university itself $[85,86]$.

However, the successful implementation, whether in research, teaching, or campus-management, is confronted with significant barriers. These barriers include overcrowded curricula, irrelevance given by lecturers to sustainability, limited knowledge of employees on sustainability, and the limited direction and commitment of the institution $[82,87]$.

Besides, there are significant barriers to the implementation of a sustainable university, for instance: the often legally guaranteed freedom of research and teaching, the lack of recognition of teachers who work with and for sustainable development, the lack of a desire for change, and the lack of pressure from society [88].

\section{Methods}

The aim of the study was to collect information about attitudes and opinions on sustainability leadership from an international group of professionals. From this, recommendations should be derived on how to tackle difficulties identified. For this purpose, two main research questions guided this 
study: (a) what are the main characteristics leaders possess and should have to work on sustainability? and (b) what are the main challenges for sustainability leadership? Further considerations in the research were given to matters, such as gender issues and the positive outcomes of sustainability leadership.

\subsection{Participants}

In order to have the basis to discuss sustainability leadership, a survey was conducted to collect information from an international sample, which was drawn by purposive and non-random sampling. The study was, therefore, explorative and did not aim in theorizing or drawing generalizable statements. In order to select information-rich and experienced participants, purposeful sampling was applied. The sample included leaders and top-management representatives (e.g., Heads of Department, Deans, Vice-Rectors, and Rectors) from a set of universities from around the world, participating in the network Inter-University Sustainable Development Research Program (IUSDRP).

\subsection{The Questionnaire}

The survey consisted of three sections (as presented in Figure 1 and Table A1). The authors prepared a battery of questions to assess essential matters related to sustainability leadership in HEI, which are a novelty to the literature. Other items of the survey built upon Visser and Courtice (2011), who published a model of sustainability leadership in practice [42], containing, among other aspects, individual characteristics of leaders (i.e., styles, traits, skills, and knowledge). The survey was initially pre-tested by members of the authors' universities to check completeness, clarity, understandability, and relevance of the questions.

\begin{tabular}{|l|l|l|}
$\begin{array}{l}\text { Background } \\
\text { (University, } \\
\text { Country, University } \\
\text { commitment to } \\
\text { sustainability) }\end{array}$ & $\begin{array}{l}\text { Work as a leader } \\
\text { (time in position, } \\
\text { style, trait, how } \\
\text { decisions are } \\
\text { made) }\end{array}$
\end{tabular}

Figure 1. Online survey sections.

Some questions allowed only one response, and others up to two responses or multiple responses (as indicated in the survey summary in Table A1).

\subsection{Data Collection Procedure}

The final version of the survey was sent to colleagues who occupy senior positions at their universities, which are members of the IUSDRP network. The online tool Google Forms was used to share the survey link. The estimated response time was 5-8 minutes, and the survey received 50 responses during the period of application (November 2019 to January 2020). The results were analyzed using simple descriptive statistics (i.e., percentages to describe frequency distributions of responses).

\section{Results and Discussion}

The purpose of the study was to collect information about attitudes and opinions on sustainability leadership from an international group of professionals. The results of an international survey amongst top-level decision-makers in universities are reported in this section. This section has been divided into four parts. The first part deals with a description of the sample, followed by a self-evaluation concerning sustainability leadership. The other sections focus on areas of particular interest, such as requirements for change, gender issues, and other difficulties faced. The results of the study provided indications of how sustainability leadership is perceived by representatives of the top management of universities. This forms the basis for the derivation of conclusions and recommendations in Chapter five. 


\subsection{Sample Analysis and Commitment to Sustainability}

The survey was answered by 50 leaders from 29 countries (Figure 2): United Kingdom, United States, Latvia, Germany, Brazil, India, Ukraine, Uganda, Nigeria, Vietnam, Austria, Zimbabwe, Guatemala, Australia, Malaysia, Canada, Bangladesh, Ghana, Romania, Belarus, Portugal, Spain, Republic of Korea, Qatar, Italy, Poland, Switzerland, Singapore, Estonia. The country with the highest number of respondents was the United States, with eight answers.

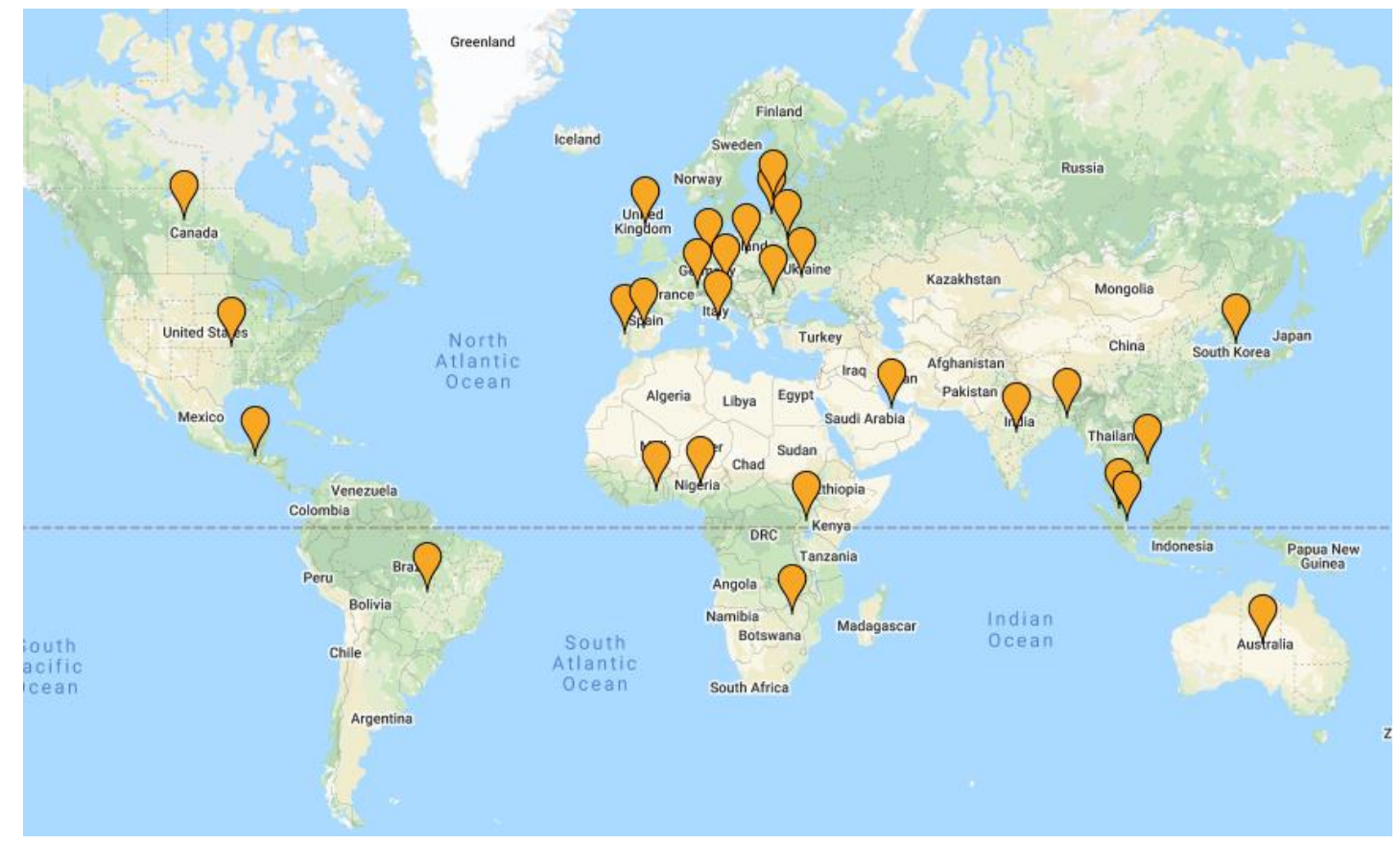

Figure 2. Participating countries.

As a non-random and purposive sampling was conducted, the results described in this section reflected only the information from this sample. After all, 50 people took part in the survey, which was a very good result considering the access difficulties in the field, in general, and with regard to the top management representatives, in particular. Despite the fact that these insights are valuable in itself, their transferability to other institutions is limited.

Regarding their experience, $46 \%$ of the sample occupied a leadership position for more than six years; $20 \%$ did it for a period between 4 to 6 years; $24 \%$ for a period between 1 to 3 years, and $10 \%$ for less than one year. In the analyzed sample, most universities were committed to sustainability: $42 \%$ to some extent, and $42 \%$ to a great extent. Sustainability was a central issue in $12 \%$ of the institutions. However, $4 \%$ of the sample informed not to be committed to sustainability yet. These institutions, which did not undertake sustainability measures, are located in Brazil and Poland.

\subsection{Self-Evaluation and Requirements Concerning Sustainability Leadership}

When asked about their style as sustainability leaders, $76 \%$ of the respondents pointed out their approach as "Inclusive"; $40 \%$ considered themselves "Visionaries"; $38 \%$ selected "Creative"; $18 \%$ "Altruistic"; only $4 \%$ selected "Radical". It is worth mentioning that each respondent could attribute up to two approaches; thus, the sum of percentages was higher than $100 \%$. Being an inclusive leader means working in a collaborative and participative way [3]. It inspires a sense of belonging [89], also contributing to a quality learning environment [39].

For the respondents' perception of their usual trait related to sustainability leadership concern, $64 \%$ considered themselves "Systemic/holistic thinkers", and 38\% indicated their trait as "Enquiring/ open-minded". The same percentage was found for "Caring/morally-driven", while $22 \%$ of the 
respondents stated "Visionary/courageous", and 20\% "Self-aware/empathetic". This topic also allowed up to two responses for each leader. According to Visser and Courtice (2011), the trait which received most responses is associated with " ... the ability to appreciate the interconnectedness and interdependency of the whole system" [3] p. 7), which means that a specific change can affect the whole system.

The respondents also identified the primary skills that a sustainability leader should possess. For this, $60 \%$ of them indicated "Challenge and innovate"; $52 \%$ reported "Manage complexity"; $40 \%$ indicated "Think long term"; $36 \%$ pointed "Communicate vision"; $4 \%$ pointed "Exercise judgment". The most stated skill contains the word "challenge", and this might be a reason for respondents to choose it-the recognition of sustainability as a challenge for HEIs [82,90]. Additionally, sustainability leaders need to overcome challenges, look for alternative solutions, and think outside the box $[3,41]$.

Regarding the knowledge that a sustainability leader should have, $68 \%$ indicated "Interdisciplinary connectedness", which is related to the same context of the triple bottom line-social, economic, and environmental connection of sustainability—and implies the relationship of all areas of expertise [3,91]. "Organizational influences and impacts" was indicated by $42 \%$ of the respondents; $40 \%$ pointed "Global challenges and dilemmas"; $26 \%$ reported "Change dynamics and options"; $22 \%$ indicated "Diverse stakeholder views". All these results are summarized in Figure 3.

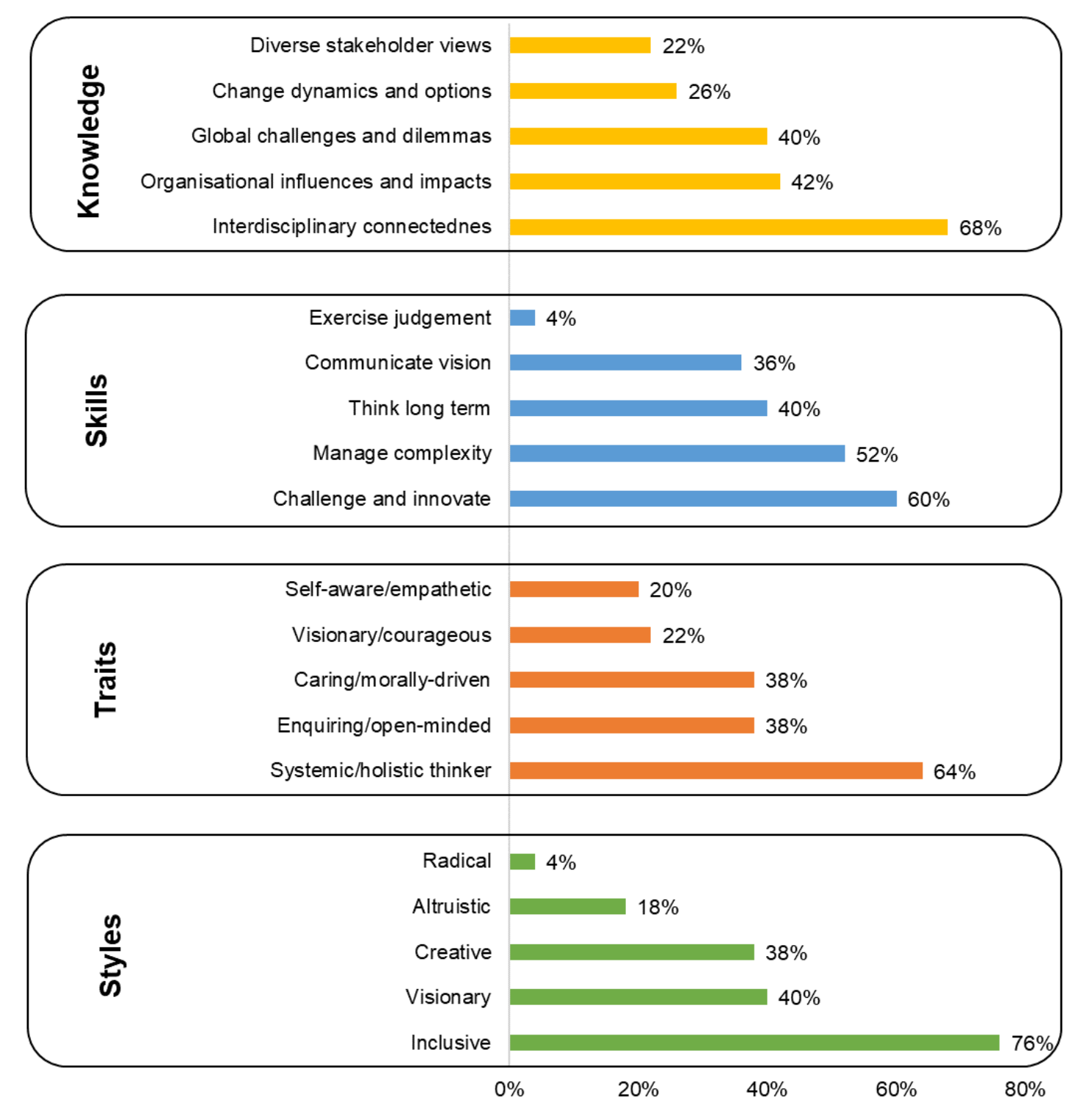

Figure 3. Knowledge, skills, traits, and styles for sustainability leadership. 
About the decisions to increase sustainability, $70 \%$ of the respondents indicated that they took these decisions "Collaboratively"; $24 \%$ did it "individually (according to a respective position)"; $4 \%$ did it through a "majority of votes"; $2 \%$ took decisions in a customized way.

\subsection{University Change Requirements}

Most of the respondents (78\% and 76\%, respectively) indicated "Curriculum Change" and "Investment in Education for Sustainability" as main actions universities should implement as a result of good sustainability leadership. The following items were indicated as actions to be taken to foster sustainability: "Green/Sustainability Office" (58\%), "Projects for the local community" (56\%), "Sustainability procurement" (44\%), "Improved sustainability reporting" (42\%).

Other actions were also pointed out as important for respondents, as described in the following list:

- Sustainable in operations (and lead by example, institutional capacity, the transition to net-zero carbon, sustainable food purchasing) $(10 \%)$

- Sustainability in research and responsible and impactful research (8\%)

- Sustainability in outreach (including stakeholders engagement and social spaces for civic engagement) $(6 \%)$

- Communication (spillover, information transparency) (4\%)

- Full alignment with the SDGs (2\%)

- Aim at sustainability in all aspects of HEI activity $(2 \%)$

\subsection{Gender Inequalities}

When gender issues were considered, only one respondent (from Brazil) affirmed that no woman is in a leadership position in their university. All the other respondents stated that there are women in leadership positions in their institutions. Concerning the percentage, $36 \%$ of the respondents indicated that women occupy more than $30 \%$ of the positions; $22 \%$ said that it ranges from $21 \%$ to $30 \% ; 14 \%$ stated that it is between $11 \%$ and $20 \%$; for $10 \%$ of the sample, the ratio was $10 \%$ or less; $16 \%$ did not know this information. These results pointed to the problem of a continuing under-representation of women in leadership positions in higher education, which is also supported by other studies $[65,69,70]$. At the same time, the results did not unequivocally support the statement of the higher commitment of newer universities to gender equality and a more significant representation of women in these positions [66]. The founding years of the universities varied significantly within each group of answers, not allowing to speculate about the relation between these two parameters.

Regarding women as sustainability leaders, $28 \%$ of the respondents stated that no activities/programs promoting women as sustainability leaders at the organization had been performed. According to $26 \%$ of the respondents, less than five of these activities/programs were executed; $14 \%$ of the leaders stated that between 5 and 15 activities/programs were done. More than 15 activities/programs were conducted only in $6 \%$ of the respondents' institutions. Finally, $26 \%$ of the sample stated not to know the answer to this question. Considering that most universities in the sample are committed to sustainability, it could be concluded that the promotion of women's leadership roles is not an essential part of their sustainability agenda.

Moreover, the respondents did not pay attention to gender-related issues and related actions that are required to overcome the challenges associated with sustainability leadership. When inquired if women are more effective sustainability leaders than men, due to their greater concern over sustainabilityrelated issues, almost half of the respondents (44\%) remained neutral, neither agreeing nor disagreeing. Additionally, when asked if they consider that the gender composition of executive leadership roles defines a level of sustainability at the organization, despite a somewhat balanced result, a few more responses indicated agreement. The last statement (concerning attention to needs and preferences of women when designing and implementing sustainability) was the one with the highest level of agreement (68\% in total). These results are presented in Figure 4. 
10. Women are more effective sustainability leaders due to their greater concern over sustainability-related issues when compared with their male counterparts regardless of positions held at the organization.

11. Gender composition of executive leadership roles defines a level of sustainability at the organization.

12. There is a necessity to pay explicit attention to needs and preferences of women when designing and implementing activities/projects/initiatives aimed at increasing
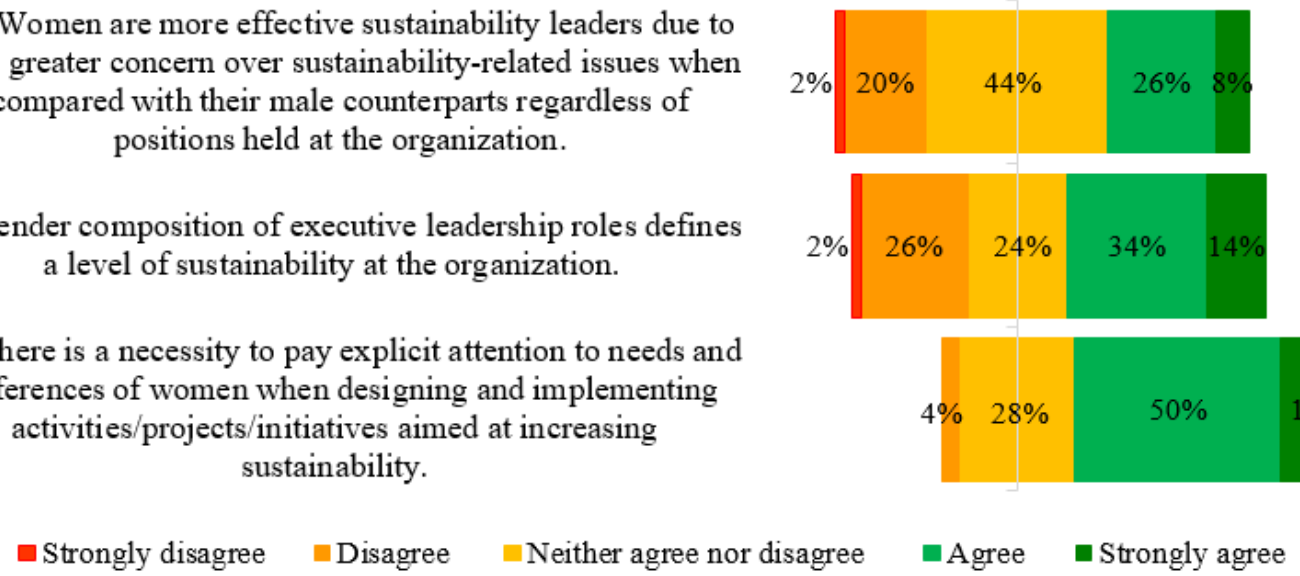

Figure 4. Results for gender statements.

The neutral to strongly disagree position of most respondents on women as better sustainability leaders could be explained by one or more of such factors as the still prevailing stereotype on women's abilities as leaders [63,71]. Women on leadership positions leaders consider their experience being leaders as gender-neutral based on merit and hard work [92], organizations do not emphasize gender nature of sustainability achievements, and there is very limited dissemination of studies on women in managerial positions as drivers to better organizational performance, including sustainability $[63,64,68,93]$.

\subsection{Difficulties Faced for Sustainability Leadership}

Regarding the difficulties faced by institutions in sustainability leadership, the lack of funding was pointed out by $80 \%$ of the respondents, corroborating the results of previous studies $[81,82]$. The lack of support from the administration was indicated by $54 \%$ of the respondents; the lack of interest from the academic community was stated by $52 \%$; the lack of expertise was indicated by $48 \%$; the lack of materials/resources was pointed out by $32 \%$. Other elements were indicated by only $2 \%$ of the respondents, and they were work and freedom embedded into the policy; political and business interests in the surrounding community; lack of understanding of sustainability issues; diversity tolerated and not valued; lack of vision; no clear mission/targets defined; vested interests; lock-ins and barriers sustained by the paradigms of growth; enthusiasm among stakeholders; unwillingness to change; lack of broad inclusion.

To overcome these difficulties and ensure proper sustainability leadership, several actions were indicated by the respondents, as presented in Table 2, where they were grouped according to similar approaches.

Although the involvement of high administration is a requirement mentioned by several studies on sustainability in higher education [84], it is crucial to highlight that this is not enough for institutions to reach practical results. What is necessary is to focus on holistic approaches [94].

One of the roles of universities is to connect to society, therefore, highlighting the importance of partnerships and projects with local communities [33,35]. Additionally, by working on "public relations", universities can reach a wide range of stakeholders by using online communications as opportunities to share actions on sustainability and results of a proper sustainability leadership [95].

Some of the actions in Table 2 refer to behavior changes and education. Sustainability awareness and willingness to contribute to organizational efforts towards sustainability are fundamental for reaching good results $[96,97]$. It demands continuous efforts and participation by the diverse actors of HEIs, especially to have sustainability embedded in the university culture [98]. The additional space for comments by the end of the survey returned many interesting insights. The respondents highlighted the importance of courage to speak-up for sustainability and to overcome challenges related to the tendency of this topic to be marginalized from important decisions. Equitable opportunities were also mentioned, especially when it comes to gender issues and how to make leading men more interested 
in sustainability. As already discussed by other studies [32-34], respondents supported the importance of impact outside the university (e.g., in local communities) and cooperation among institutions.

Table 2. Actions indicated by the respondents to overcome sustainability leadership challenges.

\begin{tabular}{|c|c|}
\hline Topic & Actions \\
\hline $\begin{array}{l}\text { Involve high } \\
\text { administration }\end{array}$ & $\begin{array}{c}\text { Greater sustainability awareness at the highest level of the university } \\
\text { (e.g., Vice-Chancellor, Deputy Vice-Chancellor, etc.) } \\
\text { Involve university rector board and administration office } \\
\text { Must be presented at all managerial levels } \\
\text { Convincing administration that sustainability is not an option but a necessity for } \\
\text { remaining a relevant educational institution and leading by doing } \\
\text { Only when a benefit for the University appears, interest may be created. }\end{array}$ \\
\hline $\begin{array}{l}\text { Partnerships/ } \\
\text { public relations }\end{array}$ & $\begin{array}{c}\text { Establishment of partnership with institutions that are making greater progress } \\
\text { and impact } \\
\text { Development of joint projects with universities, which have expertise in } \\
\text { sustainable leadership } \\
\text { Good public relations } \\
\text { Cooperation in sustainable local development projects with municipalities } \\
\text { Development of stakeholder organization networks } \\
\text { Leadership on the basis of local knowledge practice }\end{array}$ \\
\hline $\begin{array}{l}\text { Education and } \\
\text { communication }\end{array}$ & $\begin{array}{c}\text { Awareness-raising and good communication } \\
\text { A greater degree of consciousness through events, training, and calls } \\
\text { Education and funding } \\
\text { More widespread communication across the university on the global and local } \\
\text { importance, priority, and change that is and will happen } \\
\text { Continued education and awareness at all levels of the university } \\
\text { Potentializing the sustainability actions (projects, education, support to the community) } \\
\text { and disseminating them; even if they are isolated initiatives, they contribute to } \\
\text { awareness of the academic community } \\
\text { Encouragement of reflective thinking (making students voices heard) }\end{array}$ \\
\hline $\begin{array}{l}\text { Financial support } \\
\text { and planning }\end{array}$ & $\begin{array}{c}\text { More financial support and proper action plan } \\
\text { Steady funding commitment } \\
\text { Continuous investment in education for sustainability at top management level, } \\
\text { faculty members, students, and university fringe communities } \\
\text { More funding in creating solutions to be shared by all, less competition between } \\
\text { universities/people, which hinders sharing }\end{array}$ \\
\hline Policy concern & $\begin{array}{l}\text { Having broader societal and governmental concern about sustainability challenges } \\
\text { Existence of role models }\end{array}$ \\
\hline $\begin{array}{l}\text { Curriculum and } \\
\text { training }\end{array}$ & $\begin{array}{l}\text { Development of sustainability staff networks } \\
\text { More rigorous professional credentials for sustainability officers } \\
\text { Establishment of agreed sustainability principles that should be embedded in } \\
\text { educational and operational practices, as well as measurable targets that must be met } \\
\text { (and for which different stakeholders in the community are held accountable) } \\
\text { Link to the curriculum } \\
\text { Sustainability should be made part of academic assessments }\end{array}$ \\
\hline Behavior changes & $\begin{array}{l}\text { Being open-minded and going beyond the status quo } \\
\text { Sincerity of purpose } \\
\text { Persistence and patience; sustainability is undoubtedly moving up all our agendas, } \\
\text { and we will be held to account } \\
\text { More inclusivity, less in-group, out-group behavior }\end{array}$ \\
\hline
\end{tabular}

\section{Conclusions}

This study revealed a number of trends. As a start, most of the surveyed sustainability leaders described their institutions as "Inclusive", which suggested that only a few of them regarded themselves as "Radical". This finding, in turn, indicated that collaborative and participative ways of working are popular. Besides, as far as the skills of senior management are concerned, the primary skills 
that a sustainability leader should possess entailed "Challenge and innovate", "Manage complexity", and "Think long term". This was also an interesting finding since these skills do help in engaging staff and in motivating them to engage. In addition, it was evident from the responses that a sustainability leader should have "Interdisciplinary connectedness", a further ability, which helps to motivate others.

In respect of the main actions the leadership should undertake to foster institutional sustainable development, "Curriculum Change" and "Investment in Education for Sustainability" were regarded as seen as being among the most popular ones. The study also revealed that gender issues were taken seriously among the sampled institutions, which is an encouraging trend, whereas lack of funding and lack of support from administrations were listed among the main difficulties faced by institutions for sustainability leadership. It was noticeable that the involvement of senior management and the use of holistic approaches were important in handling the identified problems.

In respect to its implications for theory and practice, this study did not strive for generalizable conclusions due do its explorative character and purposive sampling. However, conclusions could be drawn from the sample. For instance, it provided a welcome addition to the literature on sustainability leadership, exploring the role of senior staff in pursuing and achieving institutional objectives toward more sustainable practices.

In addition, it showed that some Higher Education Institutions are increasingly taking leadership on sustainable development more seriously and reflecting on them. The research also illustrated the advantages that could be taken by critical sustainability leadership dialogues, which might entail research and teaching.

This study had some limitations. Firstly, reaching a greater number of participants in the online survey would have added additional robustness to the study, especially since it could have allowed a broader diversity in respect of perspectives. More participation from decision-makers would have provided a better and more representative understanding of their positions and opinions. However, the usual difficulties in engaging top management representatives in similar studies were also observed here. Whereas there is no such a thing as an ideal sample size, the fact that 50 leaders from 29 countries were involved, and bearing in mind the sample entailed representatives from industrialized and developing countries means that it caters for a rough profile, which shows the extent to which leadership perceives sustainable development.

In respect of the measures that may be adopted in the future, so as to allow Higher Education Institutions to enhance their performance, the following may be mentioned:

- Measure 1-a greater focus on practical aspects of governance, better integrating governance issues into university life.

- Measure 2-institutionalizing the incorporation of SD issues at universities, by means of a stronger embedment of concrete activities, such as the elaboration of sustainability action plans and strategies or work programs, via which senior management can better be related to academic and non-academic staff, all to the advantage of institutional practices.

- Measure 3-a greater focus on the contributions from leadership towards the attainment of the SDG targets. Here, the current levels of emphasis on the SDGs could be measured, a set of SDGs-related goals could be set, and progress toward their achievements could be assessed. The fact that senior staff act as drivers and/or moderators means that the visibility of such action will be assured.

- Measure 4-identify the means via which leadership may engage in fostering the capability of staff at their organizations to promote sustainable development. There is a paucity of leadership-led training initiatives aimed at raising awareness among academic and non-academic staff, so such an initiative may help to move this important area forward.

If properly considered and implemented, sustainability leadership may not only lead to an enhancement in the ways an institution engages on matters related to sustainable development but should also lead to a culture of institutional change, assisting an organization in finding the best ways to respond to local, regional, and global challenges. 
This research provided insights for future research. First, a greater understanding of other leadership approaches (besides the trait/style school) in the context of sustainable development could enrich this work. Thus, an exploration, for example, of the relations between university members, or dyads (leader-follower) of leadership for sustainable development, such as Rectors/Vice-Rectors; Vice-Rectors/Deans; Deans/Heads of the department; Heads of Department/Professors; Professors/Students, could be valuable. Secondly, having in mind that the context in which the university is inserted is an important variable to work with, the question of how universities organize themselves when they face changes in their external environment, reflecting this into sustainable leadership practices could be explored (e.g., how universities react and adapt their systems when they become PRME signatories). Third, since leadership in HEIs is an important and growing topic in the literature, in-depth qualitative and quantitative exploration would be fundamental to develop a robust theoretical framework capable of dealing with the complexity that is inherent to sustainability leadership, boosting the theoretical understanding. Finally, longitudinal studies could be useful to understand how several variables change over time, showing the evolution of sustainable leadership practices in HEIs.

Author Contributions: Conceptualization, W.L.F., A.L.S., J.H.P.P.E., M.W., A.C.F.C., I.S.R., R.A.; methodology, W.L.F., A.L.S., M.W., J.P., M.K., J.H.P.P.E.; formal analysis, A.L.S., M.K., M.W., J.P., A.C.F.C.; investigation, A.L.S.; supervision, W.L.F.; writing-original draft preparation, W.L.F., J.H.P.P.E., A.C.F.C., M.W., A.L.S., I.S.R., R.A., J.P., M.K.; writing-review and editing, W.L.F., M.W., J.H.P.P.E., A.C.F.C., A.L.S., I.S.R., R.A., J.P., M.K.; project administration, W.L.F.; All authors have read and agreed to the published version of the manuscript.

Funding: This research received no external funding.

Acknowledgments: In this section you can acknowledge any support given which is not covered by the author contribution or funding sections. This may include administrative and technical support, or donations in kind (e.g., materials used for experiments).

Conflicts of Interest: The authors declare no conflict of interest.

\section{Appendix A}

Table A1. Summary of the survey questions and response options.

\begin{tabular}{c}
\hline Background \\
\hline A. University \\
\hline B. Country \\
\hline
\end{tabular}

\section{Not yet}

C. Is your university committed to sustainability?

Yes, to some extent

Yes, to a great extent

Yes, it is central to our university

Your work as a leader

1. You have occupied a leadership position for:

less than 1 year

1 to 3 years

4 to 6 years

more than 6 years

2. Which style do you think describes more properly your approach as a leader as far as sustainability leadership is concerned? (please select up to two options)
Inclusive
Visionary
Creative
Altruistic
Radical

3. Which type of usual trait describes more properly your approach as far as sustainability leadership is concerned? (please select up to two options)
Caring/morally-driven Systemic/holistic thinker Enquiring/open-minded Self-aware/empathetic Visionary/courageous 
Table A1. Cont.

\begin{tabular}{|c|c|}
\hline Background & \\
\hline $\begin{array}{l}\text { 4. Decisions aimed at increasing sustainability at the } \\
\text { organization you are leading are made primarily in the } \\
\text { following way: }\end{array}$ & $\begin{array}{c}\text { majority of votes } \\
\text { collaboratively } \\
\text { individually (according to a respective position) } \\
\text { custom }\end{array}$ \\
\hline \multicolumn{2}{|l|}{ Desired aspects, gender equality and challenges } \\
\hline \multicolumn{2}{|l|}{ Desired aspects } \\
\hline $\begin{array}{l}\text { 5. In your opinion, which are the main skills a sustainability } \\
\text { leader should possess? (select up to two options) }\end{array}$ & $\begin{array}{l}\text { Manage complexity } \\
\text { Communicate vision } \\
\text { Exercise judgment } \\
\text { Challenge and innovate } \\
\text { Think long term }\end{array}$ \\
\hline $\begin{array}{l}\text { 6. In your opinion, which topics better represent the } \\
\text { knowledge a sustainability leader should possess? } \\
\text { (select up to two options) }\end{array}$ & $\begin{array}{l}\text { Global challenges and dilemmas } \\
\text { Interdisciplinary connectedness } \\
\text { Change dynamics and options } \\
\text { Organizational influences and impacts } \\
\text { Diverse stakeholder views }\end{array}$ \\
\hline $\begin{array}{l}\text { 7. Which main actions should a university implement as a } \\
\text { result of good sustainability leadership? } \\
\text { (multiple choices possible) }\end{array}$ & $\begin{array}{c}\text { Curriculum change } \\
\text { Green/Sustainability Office } \\
\text { Projects for the local community } \\
\text { Investment in Education for Sustainability } \\
\text { Improved sustainability reporting } \\
\text { Sustainability procurement } \\
\text { Other }\end{array}$ \\
\hline \multicolumn{2}{|l|}{ Gender equality } \\
\hline $\begin{array}{l}\text { 8. Are there women in leadership positions (e.g. president, } \\
\text { rector, vice-president, vice-rector, chief officers, } \\
\text { vice-chancellors, deans, heads of departments) } \\
\text { at your university? }\end{array}$ & $\begin{array}{l}\text { Yes } \\
\text { No }\end{array}$ \\
\hline $\begin{array}{l}\text { 8.1. If yes, what is the percentage of women in } \\
\text { leadership positions? }\end{array}$ & $\begin{array}{c}10 \% \text { or less } \\
11 \%-20 \% \\
21 \%-30 \% \\
\text { over } 30 \% \\
\text { don't know }\end{array}$ \\
\hline $\begin{array}{l}\text { 9. How many activities/programs promoting women as } \\
\text { sustainability leaders at the organization have been set up? }\end{array}$ & $\begin{array}{l}\text { None } \\
\text { less than } 5 \\
5-15 \\
\text { more than } 15 \\
\text { don't know }\end{array}$ \\
\hline \multicolumn{2}{|l|}{$\begin{array}{l}\text { Please specify the extent to which you agree/disagree with } \\
\text { the following statements: }\end{array}$} \\
\hline $\begin{array}{l}\text { 10. Women are more effective sustainability leaders due to } \\
\text { their greater concern over sustainability-related issues } \\
\text { when compared with their male counterparts regardless of } \\
\text { positions held at the organization. }\end{array}$ & $\begin{array}{c}\text { Strongly disagree } \\
\text { Disagree } \\
\text { Neither agree nor disagree } \\
\text { Agree } \\
\text { Strongly agree }\end{array}$ \\
\hline $\begin{array}{l}\text { 11. The gender composition of executive leadership roles } \\
\text { defines a level of sustainability at the organization. }\end{array}$ & $\begin{array}{c}\text { Strongly disagree } \\
\text { Disagree } \\
\text { Neither agree nor disagree } \\
\text { Agree } \\
\text { Strongly agree }\end{array}$ \\
\hline
\end{tabular}


Table A1. Cont.

\begin{tabular}{cc}
\hline Background & Strongly disagree \\
Disagree \\
$\begin{array}{c}\text { 12. There is a necessity to pay explicit attention to the } \\
\text { needs and preferences of women when designing and } \\
\text { implementing activities/projects/initiatives aimed at } \\
\text { increasing sustainability. }\end{array}$ & $\begin{array}{c}\text { Agree } \\
\text { Challenges }\end{array}$ \\
\hline $\begin{array}{c}\text { Strongly agree } \\
\text { 13. Which elements mostly hinder the efforts of } \\
\text { sustainability leadership? (multiple choices possible) }\end{array}$ & $\begin{array}{c}\text { Lack of expertise } \\
\text { Lack of interest from the academic community } \\
\text { Lack of funding }\end{array}$ \\
\hline $\begin{array}{c}\text { 14. Which actions do you feel are needed to overcome these } \\
\text { challenges and ensure proper sustainability leadership? }\end{array}$ & $\begin{array}{c}\text { Lack of support from administration } \\
\text { Other }\end{array}$ \\
\hline Any other comments? & \\
\hline
\end{tabular}

\section{References}

1. Sanders, N.R.; Wood, J.D. Foundations of Sustainable Business: Theory, Function, and Strategy; John Wiley \& Sons: Hoboken, NJ, USA, 2015; ISBN 978-1-119-57755-3.

2. Lozano, R.; Lukman, R.; Lozano, F.J.; Huisingh, D.; Lambrechts, W. Declarations for sustainability in higher education: Becoming better leaders, through addressing the university system. J. Clean. Prod. 2013, 48, 10-19. [CrossRef]

3. Visser, W.; Courtice, P. Sustainability Leadership: Linking Theory and Practice; Social Science Research Network: Rochester, NY, USA, 2011.

4. Finkelstein, S.; Hambrick, D.C. Top-Management-Team Tenure and Organizational Outcomes: The Moderating Role of Managerial Discretion. Adm. Sci. Q. 1990, 35, 484-503. [CrossRef]

5. Strand, R. Strategic Leadership of Corporate Sustainability. J. Bus. Ethics 2014, 123, 687-706. [CrossRef]

6. Wiersema, M.F.; Bantel, K.A. Top Management Team Demography and Corporate Strategic Change. Acad. Manag. J. 1992, 35, 91-121. [CrossRef]

7. Artigiani, R. Leadership and uncertainty: Complexity and the lessons of history. Futures 2005, 37, 585-603. [CrossRef]

8. Cicero, L.; Pierro, A.; Knippenberg, D.V. Leadership and Uncertainty: How Role Ambiguity Affects the Relationship between Leader Group Prototypicality and Leadership Effectiveness. Br. J. Manag. 2010, 21, 411-421. [CrossRef]

9. Bass, B.M.; Bass, R. The Bass Handbook of Leadership: Theory, Research, and Managerial Applications, 4th ed.; Free Press: New York, NY, USA, 2009; ISBN 978-0-7432-1552-7.

10. Lunenburg, F. Leadership versus Management: A Key Distinction-At Least in Theory. Int. J. Manag. Bus. Adm. 2011, 14, 1-4.

11. Yukl, G.A. Leadership in Organizations; Prentice Hall: Upper Saddle River, NJ, USA, 1998.

12. Kotter, J.P. The Leadership Factor; Free Press: New York, NY, USA, 1987.

13. Kotter, J.P. What Leaders Really Do; Harvard Business Review Book Series; Harvard Business School Press: Cambridge, MA, USA, 2001.

14. Kotter, J.P. Force For Change: How Leadership Differs from Management; Simon and Schuster: New York, NY, USA, 2008; ISBN 978-1-4391-3599-0.

15. Senge, P.M.; Kleiner, A.; Ross, R.; Roth, G.; Smith, B. The Dance of Change-The Challenges of Sustaining Momentum in a Learning Organization; Penguin-Random House: New York, NY, USA, 1999.

16. Zaleznik, A. Managers and Leaders: Are They Different? Available online: https://hbr.org/2004/01/managersand-leaders-are-they-different (accessed on 10 March 2020).

17. House, R.J.; Aditya, R.N. The Social Scientific Study of Leadership: Quo Vadis? J. Manag. 1997. [CrossRef] 
18. Parkin, S. The Positive Deviant: Sustainability Leadership in a Perverse World; Earthscan: London, UK, 2010; ISBN 978-1-84977-657-8.

19. Scroggins, C.; Stanley, A. How to Lead When You're Not in Charge: Leveraging Influence When You Lack Authority; Zondervan: Grand Rapids, Michigan, 2017; ISBN 978-0-310-53157-9.

20. Hill, L.A. Leading from Behind. Available online: https://store.hbr.org/product/leading-from-behind/H005FX (accessed on 10 March 2020).

21. Ferdig, M.A. Sustainability leadership: Co-creating a sustainable future. J. Change Manag. Int. J. 2007, 7, 25-35. [CrossRef]

22. Hargreaves, A.; Fink, D. Sustainable Leadership; John Wiley \& Sons: Hoboken, NJ, USA, 2012; ISBN 978-1-118-42921-1.

23. McCann, J.T.; Holt, R.A. Defining sustainable leadership. Int. J. Sustain. Strateg. Manag. 2010, 2, $204-210$. [CrossRef]

24. Broman, G.; Robèrt, K.-H.; Collins, T.J.; Basile, G.; Baumgartner, R.J.; Larsson, T.; Huisingh, D. Science in support of systematic leadership towards sustainability. J. Clean. Prod. 2017, 140, 1-9. [CrossRef]

25. Burns, H.; Miller, W. The Learning Gardens Laboratory: Teaching Sustainability and Developing Sustainable Food Systems Through Unique Partnerships. J. Agric. Food Syst. Community Dev. 2012, 2, 69-78. [CrossRef]

26. Biermann, F.; Abbott, K.; Andresen, S.; Bäckstrand, K.; Bernstein, S.; Betsill, M.M.; Bulkeley, H.; Cashore, B.; Clapp, J.; Folke, C.; et al. Navigating the Anthropocene: Improving Earth System Governance. Science 2012, 335, 1306-1307. [CrossRef] [PubMed]

27. Griggs, D.; Stafford-Smith, M.; Gaffney, O.; Rockström, J.; Öhman, M.C.; Shyamsundar, P.; Steffen, W.; Glaser, G.; Kanie, N.; Noble, I. Sustainable development goals for people and planet. Nature 2013, 495, 305-307. [CrossRef]

28. Hahn, T.; Pinkse, J.; Preuss, L.; Figge, F. Tensions in Corporate Sustainability: Towards an Integrative Framework. J. Bus. Ethics 2015, 127, 297-316. [CrossRef]

29. Hart, S.L.; Milstein, M.B. Creating sustainable value. Acad. Manag. Perspect. 2003, 17, 56-67. [CrossRef]

30. Eccles, R.G.; Perkins, K.M.; Serafeim, G. How to Become a Sustainable Company. MIT Sloan Manag. Rev. 2012, 53, 42-50.

31. UN GC The Principles for Responsible Management Education (PRME). 2018. Available online: https: //www.unprme.org/resources (accessed on 29 March 2020).

32. Blanco-Portela, N.; Benayas, J.; Pertierra, L.R.; Lozano, R. Towards the integration of sustainability in Higher Education Institutions: A review of drivers of and barriers to organisational change and their comparison against those found of companies. J. Clean. Prod. 2017, 166, 563-578. [CrossRef]

33. Leal, W.; Vargas, V.R.; Salvia, A.L.; Brandli, L.L.; Pallant, E.; Klavins, M.; Ray, S.; Moggi, S.; Maruna, M.; Conticelli, E.; et al. The role of higher education institutions in sustainability initiatives at the local level. J. Clean. Prod. 2019, 233, 1004-1015. [CrossRef]

34. Radinger-Peer, V.; Pflitsch, G. The role of higher education institutions in regional transition paths towards sustainability. Rev. Reg. Res. 2017, 37, 161-187. [CrossRef]

35. Shiel, C.; Leal Filho, W.; do Paço, A.; Brandli, L. Evaluating the engagement of universities in capacity building for sustainable development in local communities. Eval. Program Plan. 2016, 54, 123-134. [CrossRef] [PubMed]

36. Hersey, P.; Blanchard, K.H.; Natemeyer, W.E. Situational Leadership, Perception, and the Impact of Power. Group Organ. Stud. 1979, 4, 418-428. [CrossRef]

37. Lynch, B.M.; McCormack, B.; McCance, T. Development of a model of situational leadership in residential care for older people. J. Nurs. Manag. 2011, 19, 1058-1069. [CrossRef] [PubMed]

38. Papworth, M.A.; Milne, D.; Boak, G. An exploratory content analysis of situational leadership. J. Manag. Dev. 2009, 28, 593-606. [CrossRef]

39. Gill, S.; Singh, G. Developing inclusive and quality learning environments in HEIs. Int. J. Educ. Manag. 2019, ahead-of-print. [CrossRef]

40. Ploum, L.; Blok, V.; Lans, T.; Omta, O. Toward a Validated Competence Framework for Sustainable Entrepreneurship. Organ. Environ. 2018, 31, 113-132. [CrossRef]

41. Benton-Short, L.; Merrigan, K.A. Beyond interdisciplinary: How sustainability creates opportunities for pan-university efforts. J. Environ. Stud. Sci. 2016, 6, 387-398. [CrossRef]

42. Dyer, G.; Dyer, M. Strategic leadership for sustainability by higher education: The American College \& University Presidents' Climate Commitment. J. Clean. Prod. 2017, 140, 111-116. [CrossRef] 
43. Hussain, S.; Albarwani, T. Leadership for sustainability perceptions in higher education institutions in Oman. Manag. Educ. 2015, 29, 151-157. [CrossRef]

44. Kaza, S.; Natkin, L.W.; Rowse, T. Developing sustainability leadership through faculty professional development. J. Environ. Stud. Sci. 2016, 6, 437-444. [CrossRef]

45. Missimer, M.; Connell, T. Pedagogical Approaches and Design Aspects To Enable Leadership for Sustainable Development. Sustainability 2012, 5, 172-181. [CrossRef]

46. Borges, J.C.; Cezarino, L.O.; Ferreira, T.C.; Sala, O.T.M.; Unglaub, D.L.; Caldana, A.C.F. Student organizations and Communities of Practice: Actions for the 2030 Agenda for Sustainable Development. Int. J. Manag. Educ. 2017, 15, 172-182. [CrossRef]

47. Borges, J.C.; Ferreira, T.C.; Borges de Oliveira, M.S.; Macini, N.; Caldana, A.C.F. Hidden curriculum in student organizations: Learning, practice, socialization and responsible management in a business school. Int. J. Manag. Educ. 2017, 15, 153-161. [CrossRef]

48. Westley, F.; Mintzberg, H. Visionary Leadership and Strategic Management. Strateg. Manag. J. 1989, 10, 17-32. [CrossRef]

49. Basadur, M. Leading others to think innovatively together: Creative leadership. Leadersh. Q. 2004, 15, $103-121$. [CrossRef]

50. Sosik, J.J.; Jung, D.; Dinger, S.L. Values in Authentic Action: Examining the Roots and Rewards of Altruistic Leadership. Group Organ. Manag. 2009. [CrossRef]

51. Leiserowitz, A.A.; Kates, R.W.; Parris, T.M. Sustainability Values, Attitudes, and Behaviors: A Review of Multinational and Global Trends. Annu. Rev. Environ. Resour. 2006, 31, 413-444. [CrossRef]

52. Thomas, E.F.; McGarty, C.; Mavor, K.I. Aligning Identities, Emotions, and Beliefs to Create Commitment to Sustainable Social and Political Action. Personal. Soc. Psychol. Rev. 2009. [CrossRef]

53. Di Fabio, A.; Peiró, J.M. Human Capital Sustainability Leadership to Promote Sustainable Development and Healthy Organizations: A New Scale. Sustainability 2018, 10, 2413. [CrossRef]

54. Di Fabio, A. The Psychology of Sustainability and Sustainable Development for Well-Being in Organizations. Front. Psychol. 2017, 8, 1534. [CrossRef]

55. Gabel, K.; Matkin, G.S. Sustainability Leaders' Psychological Capital: A Call for Research. Sustainability 2016, 9, 255-260. [CrossRef]

56. Jiang, W.; Zhao, X.; Ni, J. The Impact of Transformational Leadership on Employee Sustainable Performance: The Mediating Role of Organizational Citizenship Behavior. Sustainability 2017, 9, 1567. [CrossRef]

57. Lans, T.; Blok, V.; Wesselink, R. Learning apart and together: Towards an integrated competence framework for sustainable entrepreneurship in higher education. J. Clean. Prod. 2014, 62, 37-47. [CrossRef]

58. Muralidharan, E.; Pathak, S. Sustainability, Transformational Leadership, and Social Entrepreneurship. Sustainability 2018, 10, 567. [CrossRef]

59. Osagie, E.R.; Wesselink, R.; Blok, V.; Lans, T.; Mulder, M. Individual Competencies for Corporate Social Responsibility: A Literature and Practice Perspective. J. Bus. Ethics 2016, 135, 233-252. [CrossRef]

60. Wesselink, R.; Blok, V.; van Leur, S.; Lans, T.; Dentoni, D. Individual competencies for managers engaged in corporate sustainable management practices. J. Clean. Prod. 2015, 106, 497-506. [CrossRef]

61. Wesselink, R.; Wals, A.E.J. Developing competence profiles for educators in environmental education organisations in the Netherlands. Environ. Educ. Res. 2011, 17, 69-90. [CrossRef]

62. Gipson, A.N.; Pfaff, D.L.; Mendelsohn, D.B.; Catenacci, L.T.; Burke, W.W. Women and Leadership: Selection, Development, Leadership Style, and Performance. J. Appl. Behav. Sci. 2017, 53, 32-65. [CrossRef]

63. Segovia-Pérez, M.; Laguna-Sánchez, P.; de la Fuente-Cabrero, C. Education for Sustainable Leadership: Fostering Women's Empowerment at the University Level. Sustainability 2019, 11, 5555. [CrossRef]

64. Haidar, N.H. Gender Leadership and Excellence: The Case of Higher Education in Lebanon. Adm. Sci. 2018, 8, 78. [CrossRef]

65. Shepherd, S. Why are there so few female leaders in higher education: A case of structure or agency? Manag. Educ. 2017, 31, 82-87. [CrossRef]

66. Bagilhole, B.; White, K. Power and Management: A Cross-Cultural Analysis of Higher Education; Bagilhole, B., White, K., Eds.; Palgrave Macmillan: London, UK, 2011; ISBN 978-0-230-23225-9.

67. Harrison, H.; Birks, M.; Franklin, R.; Mills, J. Case Study Research: Foundations and Methodological Orientations. Forum Qual. Sozialforschung Forum Qual. Soc. Res. 2017, 18. [CrossRef] 
68. Noland, M.; Tyler, M.; Kotschwar, B. Is Gender Diversity Profitable? Evidence from a Global Survey. SSRN Electron. J. 2016. [CrossRef]

69. ECU. Equality in Higher Education: Statistical Report 2015; Part 1: Staff; Equality Challenge Unit: London, UK, 2015.

70. Morley, L. The rules of the game: Women and the leaderist turn in higher education. Gend. Educ. 2013, 25, 116-131. [CrossRef]

71. OECD. Gender and Sustainable Development Maximising the Economic, Social and Environmental Role of Women; OECD: Paris, France, 2008.

72. Ko, I.; Kotrba, L.; Roebuck, A. Leaders as Males?: The Role of Industry Gender Composition. Sex Roles 2015, 72, 294-307. [CrossRef]

73. Antonakis, J.; Avolio, B.J.; Sivasubramaniam, N. Context and leadership: An examination of the nine-factor full-range leadership theory using the Multifactor Leadership Questionnaire. Leadersh. Q. 2003, 14, 261-295. [CrossRef]

74. Dulewicz, V.; Higgs, M. Assessing leadership styles and organisational context. J. Manag. Psychol. 2005, 20, 105-123. [CrossRef]

75. Porter, L.W.; McLaughlin, G.B. Leadership and the organizational context: Like the weather? Leadersh. Q. 2006, 17, 559-576. [CrossRef]

76. Krizek, K.J.; Newport, D.; White, J.; Townsend, A.R. Higher education's sustainability imperative: How to practically respond? Int. J. Sustain. High. Educ. 2012, 13, 19-33. [CrossRef]

77. Velazquez, L.; Munguia, N.; Sanchez, M. Deterring sustainability in higher education institutions: An appraisal of the factors which influence sustainability in higher education institutions. Int. J. Sustain. High. Educ. 2005, 6, 383-391. [CrossRef]

78. del Mar Alonso-Almeida, M.; Marimon, F.; Casani, F.; Rodriguez-Pomeda, J. Diffusion of sustainability reporting in universities: Current situation and future perspectives. J. Clean. Prod. 2015, 106, 144-154. [CrossRef]

79. Wright, T. Higher Education for Sustainability: Developing a Comprehensive Research Agenda. J. Educ. Sustain. Dev. 2007, 1, 101-106. [CrossRef]

80. Shriberg, M.; Macdonald, L. Sustainability Leadership Programs: Emerging Goals, Methods \& Best Practices. J. Sustain. Educ. 2013, 5.

81. Di Carlo, F.; Modugno, G.; Agasisti, T.; Catalano, G. Changing the Accounting System to Foster Universities' Financial Sustainability: First Evidence from Italy. Sustainability 2019, 11, 6151. [CrossRef]

82. Leal Filho, W.; Pallant, E.; Enete, A.; Richter, B.; Brandli, L.L. Planning and implementing sustainability in higher education institutions: An overview of the difficulties and potentials. Int. J. Sustain. Dev. World Ecol. 2018, 25, 713-721. [CrossRef]

83. Wals, A.E.J. Sustainability in higher education in the context of the UN DESD: A review of learning and institutionalization processes. J. Clean. Prod. 2014, 62, 8-15. [CrossRef]

84. Shawe, R.; Horan, W.; Moles, R.; O'Regan, B. Mapping of sustainability policies and initiatives in higher education institutes. Environ. Sci. Policy 2019, 99, 80-88. [CrossRef]

85. van Weenen, H. Towards a vision of a sustainable university. Int. J. Sustain. High. Educ. 2000, 1, $20-34$. [CrossRef]

86. Biasutti, M.; Makrakis, V.; Concina, E.; Frate, S. Educating academic staff to reorient curricula in ESD. Int. J. Sustain. High. Educ. 2018, 19, 179-196. [CrossRef]

87. Dawe, G.; Jucker, R.; Martin, S. Sustainable Development in Higher Education: Current Practice and Future Developments. Available online: https:/www.heacademy.ac.uk/system/files/sustdevinHEfinalreport.pdf (accessed on 10 March 2020).

88. Ferrer-Balas, D.; Adachi, J.; Banas, S.; Davidson, C.I.; Hoshikoshi, A.; Mishra, A.; Motodoa, Y.; Onga, M.; Ostwald, M. An international comparative analysis of sustainability transformation across seven universities. Int. J. Sustain. High. Educ. 2008, 9, 295-316. [CrossRef]

89. Randel, A.E.; Galvin, B.M.; Shore, L.M.; Ehrhart, K.H.; Chung, B.G.; Dean, M.A.; Kedharnath, U. Inclusive leadership: Realizing positive outcomes through belongingness and being valued for uniqueness. Hum. Resour. Manag. Rev. 2018, 28, 190-203. [CrossRef]

90. Leal, W.; Skanavis, C.; Kounani, A.; Brandli, L.L.; Shiel, C.; do Paco, A.; Pace, P.; Mifsud, M.; Beynaghi, A.; Price, E.; et al. The role of planning in implementing sustainable development in a higher education context. J. Clean. Prod. 2019, 235, 678-687. [CrossRef] 
91. Liu, J.; Bawa, K.S.; Seager, T.P.; Mao, G.; Ding, D.; Lee, J.S.H.; Swim, J.K. On knowledge generation and use for sustainability. Nat. Sustain. 2019, 2, 80-82. [CrossRef]

92. Carvalho, T.; Diogo, S. Women Rectors and Leadership Narratives: The Same Male Norm? Educ. Sci. $2018,8,75$. [CrossRef]

93. Harrison, J.; Klotz, L.E. Women as Sustainability Leaders in Engineering: Evidence from Industry and Academia in the U.S. Int. J. Eng. Educ. 2010, 26, 727-734.

94. Findler, F.; Schönherr, N.; Lozano, R.; Reider, D.; Martinuzzi, A. The impacts of higher education institutions on sustainable development: A review and conceptualization. Int. J. Sustain. High. Educ. 2019, 20, $23-38$. [CrossRef]

95. Amey, L.; Plummer, R.; Pickering, G. Website communications for campus sustainability: An analysis of Canadian universities. Int. J. Sustain. High. Educ. 2020. ahead-of-print. [CrossRef]

96. Alkhayyal, B.; Labib, W.; Alsulaiman, T.; Abdelhadi, A. Analyzing Sustainability Awareness among Higher Education Faculty Members: A Case Study in Saudi Arabia. Sustainability 2019, 11, 6837. [CrossRef]

97. Klaniecki, K.; Wuropulos, K.; Hager, C.P. Behaviour Change for Sustainable Development. Encycl. Sustain. High. Educ. 2019, 1-10. [CrossRef]

98. Adams, R.; Martin, S.; Boom, K. University culture and sustainability: Designing and implementing an enabling framework. J. Clean. Prod. 2018, 171, 434-445. [CrossRef]

(C) 2020 by the authors. Licensee MDPI, Basel, Switzerland. This article is an open access article distributed under the terms and conditions of the Creative Commons Attribution (CC BY) license (http://creativecommons.org/licenses/by/4.0/). 